ノート・ Note

\title{
Analysis of Oxygen-18 in Solid Oxides by Spark Source Mass Spectrometry
}

\author{
By \\ Mitsuko NAKANO, Goro YAMAGUCHI and Kazuya SAITO \\ (Department of Industrial Chemistry, Faculty of Engineering, University of Tokyo, Tokyo)
}

スパーク放電形質量分析計による固体酸化物中の酸素-18 の分析

\author{
中野みつ子・山口悟郎・斎藤一也 \\ (東京大学工学辯工業化学科)
}

In order to clarify the mechanism of solid state reaction involving solid oxides, it is often necessary to know a part oxygen plays in it. Three kinds of radioisotopes of oxygen are unsuitable for tracers, since they all have too short half-lives. Then the stable isotope, ${ }^{17} \mathrm{O}$ or ${ }^{18} \mathrm{O}$, must be used for the study of the solid state reaction. J.B. Holt ${ }^{1)}$ studied the formation of $\mathrm{CoAl}_{2} \mathrm{O}_{4}$ from $\mathrm{CoO}$ and $\mathrm{Al}_{2} \mathrm{O}_{3}$ using oxides enriched in ${ }^{18} \mathrm{O}$. In his study ${ }^{18} \mathrm{O}$ was detected by making use of the ${ }^{18} \mathrm{O}(\mathrm{p}, \mathrm{n}){ }^{18} \mathrm{~F}$ nuclear reaction and autoradiography. However, mass spectrometry is a more direct method of detecting the stable isotope, so we attempted to apply the spark source mass spectrometry to the analysis of ${ }^{18} \mathrm{O}$ in solid oxides.

The instrument we used in this experiment was a Japan Electron Optics Laboratory JMS-0 1 B double forcusing mass spectrometer. In the case of the application of the instrument to oxide insulators such as $\mathrm{MgO}$ and $\mathrm{Al}_{2} \mathrm{O}_{3}$, some devices were needed in the method of spark excitation. In general, powdered insulators are mixed with high-purity graphite powder and then pressed into a mould to form electrodes. But this technique is unsuitable for the analysis of oxygen, since graphite powder is apt to adsorb moisture. Besides, for the purpose of the analysis it is preferable that a single crystal or a sintered specimen is analyzed as it is in a state of a lump. After some trials, such method was adopted successfully that a solid specimen was wound around by high-purity gold wire with $0.3 \mathrm{~mm}$ diameter and attached to a sample holder, and a pointed gold wire with $1 \mathrm{~mm}$ diameter was set as a counter-electrode. This specimen-electrode configuration is similar to that reported by $M$. Desjardins and others ${ }^{2}$, and the photograph of our configuration is shown in Fig. 1 .

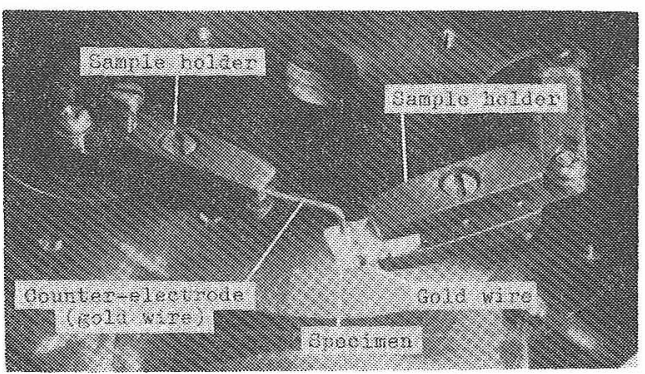

Fig. 1. Specimen-electrode configuration for spark excitation.

In the next place the influence of water adsorbed on the surface of the specimen becomes into question. The mass of ${ }^{18} \mathrm{O}, 17.9992 \mathrm{amu}$, is very close to that of ${ }^{1} \mathrm{H}_{2}{ }^{16} \mathrm{O}, 18.0106 \mathrm{amu}$. These mass spectra are separated sufficiently by the improvement of the resolution through regulation of the instrument. But oxygen, a constituent of water, possibly affects a result, so it is necessary to remove the water adsorbed on the surface of the specimen as much as possibly. As a result of many experiments the procedure described below was adopted: An electric heater was set in the $\mathrm{BeO}$ insulator that supported the sample holder on the ion source chamber. After the specimen was attached to the sample holder and the ion source chamber was evacuated, the specimen was heated for 30 minutes by use of the heater. Though the temperature of the specimen was not measured, it was estimated to be between $200^{\circ} \mathrm{C}$ and $300^{\circ} \mathrm{C}$, while a vacuum of $\simeq 10^{-7} \mathrm{mmHg}$ was maintained. The spark excitation was started after the specimen and the ion source chamber were cooled enough. Fig. 2. shows mass spectra of $\mathrm{MgO}$ detected on Ilford Q 2 photoplate. The spectrum of ${ }^{1} \mathrm{H}_{2}{ }^{16} \mathrm{O}$ is recognized to disappear after the use of the 


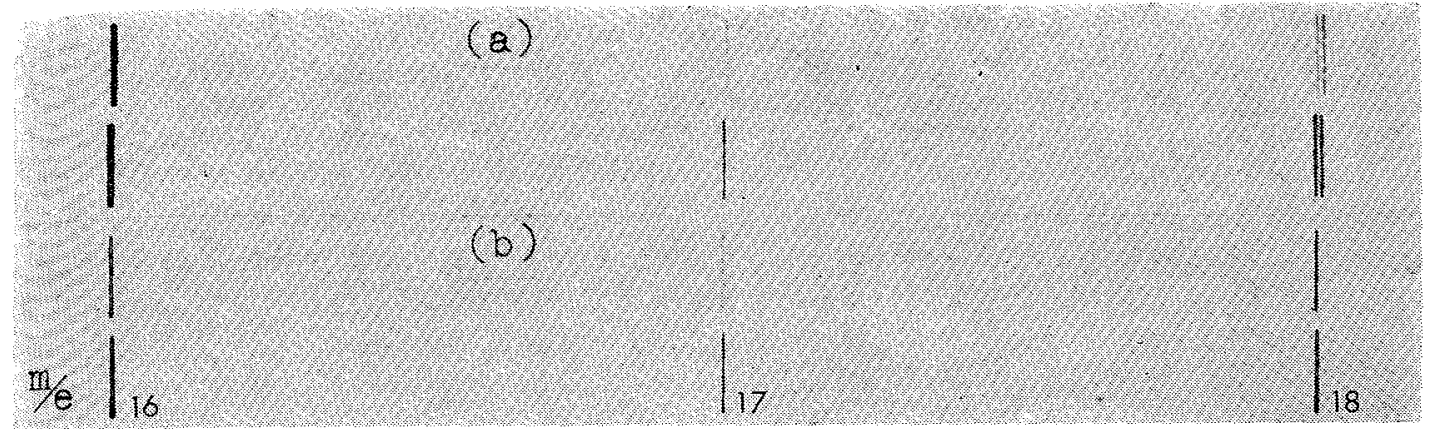

Fig. 2. Partial mass spectra of $\mathrm{MgO}:$ (a) before the use of the heater, (b) after the use of the heater.

Table 1. Exposure ratios at equal densities.

\begin{tabular}{ccc}
\hline Run & \multicolumn{2}{c}{ Exposure ratio } \\
No. & $\frac{\left.\mathrm{q}^{(16} \mathrm{O}^{+}\right)^{*}}{\mathrm{q}\left({ }^{18} \mathrm{O}^{+}\right)}$ & $\frac{\left.\mathrm{q}^{(24} \mathrm{Mg}^{+}\right)^{* *}}{\left.\mathrm{q}^{(18} \mathrm{O}^{+}\right)}$ \\
\hline 1 & $6.8 \times 10^{-2}$ & $6.4 \times 10^{-2}$ \\
2 & $6.3 \times 10^{-2}$ & $1.0 \times 10^{-1}$ \\
3 & $6.6 \times 10^{-2}$ & $1.2 \times 10^{-1}$ \\
4 & $6.0 \times 10^{-2}$ & $1.3 \times 10^{-4}$ \\
\hline Average & $6.4 \times 10^{-2}$ & $1.0 \times 10^{-1}$ \\
\hline
\end{tabular}

* The natural abundance of ${ }^{16} \mathrm{O}$ is $99.759 \%$.

** The natural abundance of ${ }^{24} \mathrm{Mg}$ is $78.70 \%$.

heater.

The results of the analysis of ${ }^{18} \mathrm{O}$ in normal $\mathrm{MgO}$ and ${ }^{18} \mathrm{O}$-enriched $\mathrm{MgO}$ are described below as an example. $\mathrm{Mg}^{18} \mathrm{O}$ was prepared by the following reactions :

$$
\begin{aligned}
& 3 \mathrm{Mg}+\mathrm{N}_{2} \rightarrow \mathrm{Mg}_{3} \mathrm{~N}_{2}, \\
& \text { carried out at } 850^{\circ} \mathrm{C} \text { for } 6 \text { hours, } \\
& \mathrm{Mg}_{3} \mathrm{~N}_{2}+6 \mathrm{H}_{2}{ }^{18} \mathrm{O} \rightarrow 3 \mathrm{Mg}\left({ }^{18} \mathrm{OH}\right)_{2}+2 \mathrm{NH}_{3}, \\
& \mathrm{Mg}\left({ }^{18} \mathrm{OH}\right)_{2} \rightarrow \mathrm{Mg}^{18} \mathrm{O}+\mathrm{H}_{2}{ }^{18} \mathrm{O},
\end{aligned}
$$

carried out at $1000^{\circ} \mathrm{C}$ in argon atmosphere. The concentration of ${ }^{18} \mathrm{O}$ in ${ }^{18} \mathrm{O}$-enriched water used in this experiment was 8.6 atom \%

The quantitative analysis was performed by taking consecutive exposures based on monitored charges $q$ as shown in Table 1. At the time of spark excitations, ions are generated from not only the specimen but also the gold wire. Therefore it is suitable to compare the density of the spectrum of ${ }^{18} \mathrm{O}$ with that of a main component. About ${ }^{18} \mathrm{O}$-enriched $\mathrm{MgO}$, the exposure ratios giving equal density of a standard ion spectrum, a spectrum of ${ }^{16} \mathrm{O}^{+}$or ${ }^{24} \mathrm{Mg}^{+}$, to ${ }^{18} \mathrm{O}^{+}$spectrum were determined with a microdensitometer. The results are shown in Table 1 . Table 1 shows ${ }^{16} \mathrm{O}^{+}$ is preferable to ${ }^{24} \mathrm{Mg}^{+}$as a standard from the view point of reproducibility. The inverse ratio of exposure of ${ }^{18} \mathrm{O}^{+}$spectrum to that of ${ }^{16} \mathrm{O}^{+}$ spectrum is considered to be equal to the ratio of concentration of ${ }^{18} \mathrm{O}$ to that of ${ }^{16} \mathrm{O}$, since the sensitivities of those two spectra are regarded to be equal. In this manner the concentrations of ${ }^{18} \mathrm{O}$ in normal $\mathrm{MgO}$ and ${ }^{18} \mathrm{O}$-enriched $\mathrm{MgO}$ were
Table 2. Determination of ${ }^{18} \mathrm{O}$ in $\mathrm{MgO}$.

\begin{tabular}{lc}
\hline \multicolumn{1}{c}{ Specimen } & $\begin{array}{c}\text { Conc. of }{ }^{18} \mathrm{O} \\
\text { (atom \%) }\end{array}$ \\
\hline Normal $\mathrm{MgO}$ & 0.21 \\
${ }^{18} \mathrm{O}$-enriched $\mathrm{MgO}$ & 6.0 \\
\hline
\end{tabular}

Table 3. Dimensions of excitation craters.

\begin{tabular}{cccc}
\hline Specimen & $\begin{array}{c}\text { Monitor charge } \\
(\text { coulomb })\end{array}$ & $\begin{array}{c}\text { Diameter } \\
(\mu)\end{array}$ & $\begin{array}{c}\text { Depth } \\
(\mu)\end{array}$ \\
\hline Single-crystalline & $1 \times 10^{-10}$ & $\simeq 500$ & $\simeq 10$ \\
MgO & $1 \times 10^{-11}$ & $\simeq 200$ & $<5$ \\
Polycrystalline & $1 \times 10^{-10}$ & $\simeq 700$ & $\simeq 20$ \\
MgO & $1 \times 10^{-11}$ & $\simeq 300$ & $\simeq 5$ \\
\end{tabular}

determined as shown in Table 2. The value obtained about normal $\mathrm{MgO}$ is consistent with the natural abundance of ${ }^{18} \mathrm{O}, 0.204$ atom $\%$.

At the time of spark excitation, craters were produced on the specimen surface. The diameters and depthes of craters were measured by the microscopy as shown in Table 3 . Therefore it is possible to maintain the depth of sampling within the order of $5 \mu$ by shifting a spark point at every spark excitation of $1 \times 10^{-11}$ coulombs.

The rate of self-diffusion of oxygen in solid oxides is frequently required in the study of solid state reaction, sintering, electric properties of oxides etc. Nearly all investigations of oxygen self-diffusion in solid oxides have been performed by the gaseous exchange method. This method precludes the experimental determination of the ${ }^{18} \mathrm{O}$ distribution in the oxide and is insufficient to clarify the mechanism of oxygen diffusion. Therefore, the analysis method stated in this note will be applied validly to determine the ${ }^{18} \mathrm{O}$ diffusion profile in the solid oxide.

\section{Peferences}

1) J.B. Holt, UCRL-12396 (1965)

2) M. Desjardins and J.P. Williams, J. Am. Ceram. Soc. 51 (5) 296-97 (1968).

[Received 6/17/1970] 